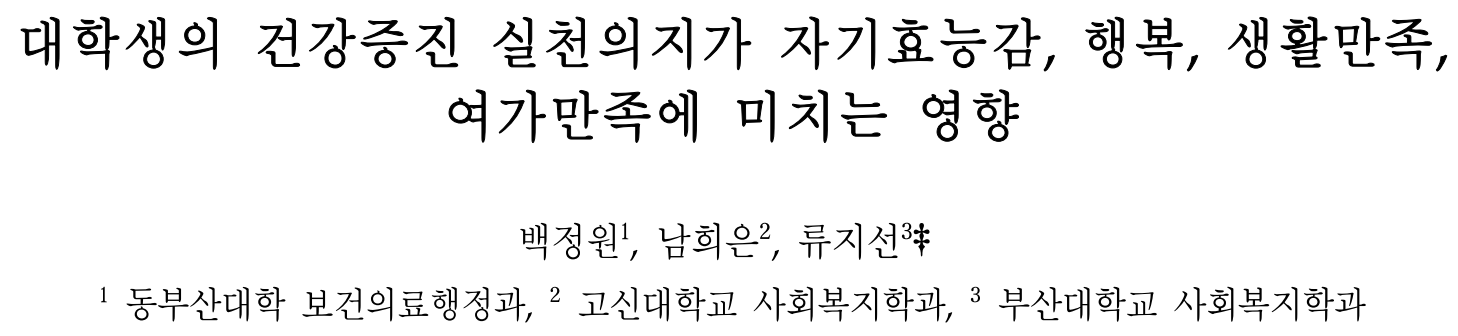

\title{
The Effects of the College Students' will for the Improvement of Health Playing on Self-Efficacy, Happiness, Life Satisfaction and Leisure Satisfaction
}

\author{
${ }^{1}$ Jeong-Won Baik, ${ }^{2}$ Hee-Eun Nam, Ji-Sun Ryu ${ }^{3 \ddagger}$ \\ ${ }^{1}$ Dep. of Health Administration, Dong-Pusan College University, \\ ${ }^{2}$ Dep. of Social Welfare, Kosin University, \\ ${ }^{3}$ Dep. of Social Welfare, Busan National University
}

\begin{abstract}
$<$ Abstract $>$
This study is designed to look into the relations between college students' will for the improvement of their health and self-efficacy, happiness, life satisfaction and leisure satisfaction. To achieve this, a survey was carried out from November 2011 to December 2011, targeting 876 college students in 10 different regions in Busan and Gyeongsangnam-do area. From the questionnaires, undependable and inappropriate questionnaires were excluded and 812 questionnaires were used for analysis data in descriptive statistics, variance analysis and simple regression analysis.

The results are as follows.

The groups with the strong show higher self-efficacy, have more happiness and express better life satisfaction.

It has been empirically proved that those college students with a strong will to improve their health love themselves more and value themselves higher, which has positive influences on their happiness, life satisfaction and leisure satisfaction.
\end{abstract}

Key Words : Determinants of Happiness, Cognition of Health, Indicators of Happiness 


\section{I . 서론}

급격한 사회변화 속에서 사람들의 삶의 질과 행 복에 대한 관심은 인간의 가장 기본적인 욕구이자, 지향점이다. 특히 자신의 신체와 직결된 건강에 대 한 관심은 남녀노소를 불문하고 보편적 현상으로 보여진다. 인간은 생존을 위한 생활에서 삶의 질을 추구하는 복지사회로 향하는 과정에 삶에 대한 높 은 관심, 행복, 웰빙, 건강 등에 주목하게 되며, 특 히 건강한 삶은 모든 인간의 권리로써 신체적, 정 신적, 사회적 건강한 상태의 유지는 가장 선행되는 생존의 조건으로 행복한 삶을 영위하는데 가장 기 초적인 부분이라고도 말 할 수 있다.

후기청소년기에 해당하는 대학생의 경우, 건강 에 대하여 깊이 고민하지 않는다. 이는 이제 청소 년기를 거쳐 이제 성인으로 몸과 마음이 완성되어 가는 시기이기도 하며, 체력적으로 가장 왕성하고 건강한 생애주기에 해당되기 때문이다. 하지만 대 학생은 신체적, 정서적, 사회적 변화를 겪으며, 성 인기 건강습관이 만들어지는 중요한 시기이기 때 문에, 이 시기의 건강관리는 남은 인생의 건강을 좌우할 수 있는 중요한 일이다. 따라서 삶에 있어 건강의 중요성을 인식하고 건강증진을 실천하게 하는 것은 국민건강증진에 도움이 되는 의의 있는 일이다. 건강은 인간의 행복과 삶의 질에 있어 가 장 기본이 되는 요인으로 대학생들도 건강이 우선 되어야 긍정적인 태도로 삶에 대한 만족과 행복감 을 느끼며, 미래를 위하여 노력하고 인생을 만들어 갈 수 있다.

우리나라의 대학생들은 고등학교를 졸업하기 직 전까지 개인적인 행복과 여가에 대한 옥구를 누르 고 과도한 학업에만 열중해야 하는 환경에 놓여있 다. 대학생이 되어서야 자기 스스로 생활을 통제하 고 관리하며, 스스로의 정체성을 찾을 수 있는 여 건이 주어지지만, 대학생 시기에 건강을 기본으로 하여 자신의 신체적, 사회적, 정신적, 정서적인 건
강과 행복을 어떻게 만들어 가야할지 잘 모르는 경우가 많다. 이에 자신에 대한 애정과 생활전반의 만족, 학교의 생활만족, 여가만족 갑자기 증가된 여가시간을 어떻게 선용할 것인가에 대한 교육이 필요하다.

Bandura(1977)는 특정 행동에 대한 낮은 자기 효능감은 그 행동을 회피하게 하는 반면에, 높은 자기 효능감은 더 적극적으로 접근하게 하는 경향 이 있다고 하였다. 또한 자기효능감은 특정 행동이 나 행동변화의 중요한 중재자로서 역할을 한다[1]. 이러한 점에서 건강증진 실천의지가 높은 대학생 의 경우, 자기효능감도 높을 것으로 예측된다. 또 한 여가활동은 삶의 질적 향상, 자아실현, 행복추 구, 건강증진의 역할뿐만 아니라 인간의 최고옥구 인 자아실현을 이룰 수 있는 원동력이 된다[2]. 이 에 본 연구에서는 행복, 삶의 질과 깊은 연관이 있 는 여가만족에 건강증진실천의지가 긍정적인 영향 을 미치는지 파악하고자 하였다.

따라서 본 연구는 건강의 중요성을 인식하고, 이러한 건강유지를 위해 건강증진을 위한 실천의 지를 가진 대학생들이 자신을 더 사랑하며, 효능감 이 높고, 생활만족이 높아 행복감을 더 느끼며, 여 가만족도 높을 것이라는 예측을 하였으며, 이를 검 증하고자 하였다.

\section{ㅍ. 이론적 배경}

\section{1. 건강증진에 관한 선행연구}

인간은 사회적 동물로서, 타인을 대할 때 자신 과 상호의존적 사회관계를 맺을 대상으로서 적합 한지 여부를 지속적으로 파악하고자 한다[3]. 김태 운(2002)의 연구에서는 여가활동 참여 대학생의 라 이프스타일과 건강증진 행위에 대한 조직만족도 간의 인과관계 연구에서 매개변인으로 설정한 건 
강증진 행위 개념의 신뢰성이 입증된 바 있다[4]. 대부분의 인간은 일상생활 중 긍정적이고 적극적 인 방법으로 자신의 건강을 유지, 증진하고자 한 다. 특히 지속적으로 건강증진행위를 수행하는 것 은 자신의 건강수준을 높이고 자아충만감을 극대 화하면서 질병을 피하고 만족을 얻으며 건강을 유 지하는 바람직한 건강습관이며 일상생활의 양식이 자 자아실현을 위한 노력임을 밝히고 있다[5]. 또 한 죽음과 질병, 장애를 초래하는 건강문제 역시 흡연, 음주 등의 건강 위해행위 조절, 식이조절, 좌 식생활 방지 등과 같은 건강증진행위를 젊은 시절 부터 시작하여 감소시킬 수 있다[6]. 초기성인은 점차적으로 자신의 건강에 대한 책임감을 가지게 되나 불건강한 습관과 행동 때문에 건강을 해치는 경우도 많으므로 이에 속하는 대학생도 건강증진 행위를 바르게 정립하는 것이 건강관리에 매우 중 요하다.

한편 우리나라의 연구에서는 김남순과 송현종의 연구에서 살펴보면 성(gender) 인지적 차이가 주목 을 받으면서 이를 바탕으로 하는 정책수립이 필요 하고 건강문제도 성별차이에 대한 관심을 높여 생 애주기별로 여성의 건강문제 등 다양한 정책적 과 제를 수행하고 있다[7]. 실제적으로 한국 성인초기 20-24세 남성의 기대여명(life expectancy)은 54.7세, 여성은 61.5세로 여성이 더 오래 생존하지만 남성 의 건강여명(disability-free life expectancy)은 46.8 세, 여성은 44.9세로 여성의 건강여명이 남성보다 짧아 성별에 따라 건강상태가 다르고 특히 여성건 강이 남성보다 열악하므로 여성건강을 유지 증진 하는데 노력해야 한다. 한국여성개발원의 연구를 살펴보면 20-29세 성인의 건강관리 방법은 '없다' 고 응답한 여성비율이 $49 \%$, 남성비율이 $45 \%$ 로 과 반수 정도가 일상생활 중 특별하게 건강을 관리하 는 방법이 없으며, 건강위해행위에 대표적인 흡연 과 음주도 20-29세 남성의 흡연자가 $60 \%$ 나 되어 여성의 $3 \%$ 에 비해 흡연율이 매우 높아 성별 차이
를 보였다. 음주는 음주문화의 관대함 때문에 20-29세 남성과 여성 모두 거의 음주를 하며, 남성 은 월 2-3회(33.6\%)와 주1-2회(29.2\%)에 속하는 경 우가 과반수를 넘었고, 여성은 월 2-3회(28.1\%)이나 여성의 신체특성 상 음주로 인해 쉽게 부정적 영 향을 받는다는 점을 감안할 때 이를 간과할 수 없 다[8]. 따라서 성별에 따른 대학생의 건강증진행위 비교연구는 프로그램마련의 기초 자료로써 의의가 있다.

김주현 외의 연구를 살펴보면 현재까지의 초기 성인인 대학생을 대상으로 한 건강증진행위 연구 결과, 대학생의 건강증진행위 수행정도나 건강증진 생활양식 이행정도가 낮은 편이고[9] 건강증진프로 그램 운영을 위한 기초 자료로 건강증진행위 영향 요인 연구는 류은정, 권영미, 이건세[10]는 사회 심 리적 건강을, 김주현, 김성재와 박연환[9]이 자기효 능감, 유익성 지각, 장애성 지각, 건강상태와 건강 중요성을, 이현주[8]가 사회적 지지를, 장애성 지 각, 이익성 지각, 상황적 장애, 자아 존중감, 자기 효능 및 사회적 지지라고 보고하였으나 단편적이 며 영형요인들의 건강증진행위에 대한 설명력이 낮다. 또한 성별에 따라 건강증진 행위도 상반된 결과를 제시하고 있어 지속적으로 일관성 있는 결 과를 모색할 필요가 있다.

\section{III. 연구방법}

\section{1. 조사 대상 및 조사 시기}

본 연구의 조사 대상자는 부산 경남에 소재하는 대학교 10곳(고신대, 부산대, 동아대, 부경대 외 6 개교)에서 설문 조사를 실시하였다. 대학에 재학 중인 1학년에서 4학년 대학생 876 명이다. 표본 추 출방법은 비확률 표본추출방법인 임의 표본추출방 법을 이용하여 자기기입식 설문지를 실시하여 총 
876 개의 설문지가 수거 되었다. 조사의 시기는 2010년 11월부터 12월까지 1동안 실시되었다. 조사 는 개별 기관별로 담당교수의 수업시간에 이루어 졌으며 최대한 자유로운 분위기에서 이루어졌다. 이 중에서 응답이 미비하거나 문항에 불성실하게 응답한 설문지를 제외하고 총 812 개의 설문지를 대상으로 분석하였다.

\section{2. 조사도구}

1) 건강증진 실천의지

건강증진 실천의지의 문항은 황홍구[10]가 대학 생들의 건강증진행위 영향요인의 연구에 사용되었 던 조사도구를 활용하였다. 황홍구의 연구[10]에서 건강증진실천의지의 신뢰도는 0.831 이었으며, 본 연구에서는 Cronbach's $a=.815$ 이다.

\section{2) 자기효능감}

일반자기효능감 척도(New General Self-Efficacy Scale: NGSE)는 최근에 조직연구자들이 자기효능 감의 특성 일반화차원에 좀 더 관심을 가지게 되 면서 Chen, Gully와 Eden(2008)이 개발한 것이다. 일반자기효능감이란 Bandura의 자기효능감 이론을 확장한 것으로, "광범위하고 다양한 성취상황에서 필수적인 수행에 영향을 미치는 개인의 전반적이 능력에 대한 개인의 신념"으로 정의된다. NGSE는 다양한 일영역에 걸쳐 동기적인 반응과 행동을 예 측할 수 있는 경향성 구인을 측정하기 위한 것으 로, NGSE 척도가 다양한 맥락에서 동기와 수행을 설명하는데 도움이 될 수 있을 것으로 생각된다. 문항은 많은 시간을 요하지 않도록 Likert 5점 척 도의 8 문항으로 구성되었으며, 본 연구에서는 Cronbach's $a=.900$ 이었다.

3) 옥스퍼드 행복설문

본 연구는 행복지수를 측정하기 위해서
Hills\&Argyle(2002)이 개발한 옥스퍼드 행복지수 척도(Oxford Happiness Questionnaire)를 사용하 였다. 본 척도는 행복감을 측정하기 위한 것으로 주관적 안녕감(subjective well-being)과 관련되며 총 29문항으로 구성되어 있다. 본 연구에서는 Cronbach's $a=.900$ 이었다.

\section{4) 생활만족}

참가자들의 전반적인 삶의 만족도를 측정하기 위해, 삶의 만족도(Satisfactin with Life Scale; Diener, Emmons, Larsen, \& Griffin, 1985)문항들 을 사용하였다. 이는 자신의 삶에 얼마나 만족하고 있는가를 측정하는 5 문항으로 구성되어 있으며(예, 나는 나의 삶에 만족한다) 7점 척도 상에 평정하도 록 하였다 $(1=$ 전혀 동의하지 않는다, $7=$ 매우 동의 한다). 본 연구에서는 5 점 척도로 변환하여 사용하 였다.

5) 여가만족

여가만족의 측정도구는 Ragheb \& Beard이 개 발한 여가만족척도(Leisure satisfaction Scale : LSS)를 활용하였다. 이 도구의 신뢰도와 타당도는 조사 도구로 적절하며, 신뢰도는 전체 .96 , 심리적 영역은 .86 , 교육적 영역은 .90, 사회적 영역은 .88, 이완은 .85 , 신체적 영역은 .92, 심미적 영역은 .86 으로 알려져 있다[11]. 본 연구에서 Cronbach's a $=.901$ 이었다.

\section{3. 연구문제}

이에 본 연구에서는 다음과 같은 연구문제를 도 출하였다.

1) 대학생의 건강증진 실천의지는 행복감과 양 $(+)$ 의 상관관계가 있을 것이다.

2) 대학생의 건강증진 실천의지는 자기효능감과 양 $(+)$ 의 상관관계가 있을 것이다. 
3) 대학생의 건강증진 실천의지는 생활만족도와 양 $(+)$ 의 상관관계가 있을 것이다.

4) 대학생의 건강증진 실천의지는 여가만족도와 양 $(+)$ 의 상관관계가 있을 것이다.

\section{4. 자료 분석 방법}

본 연구는 SPSS 18.0 프로그램을 사용하여 조사 대상자의 일반적 특성을 파악하기 위해서 빈도분 석, 평균 등의 기술적 통계(Descriptive Statistics)를 실시하였다. 또한 위의 4 가지의 연구문제를 측정하 기 위해 독립 변수인 대학생의 건강증진 실천 의 지를 점수에 따라 상, 중, 하 3 개 집단으로 분류하 였다. 연구문제 1 번, 2 번, 3 번, 4 번을 측정하기 위 해 첫째, 건강증진 실천의지와 행복, 자기효능감, 생활만족, 여가만족 항목과의 상관분석을 실시하였 고 둘째, 건강증진 실천의지 수준별로 행복, 자기 효능감, 생활만족, 여가만족의 평균을 비교하는 분 산분석(ANOVA)를 실시하였다. 또한, 건강증진 실 천의지가 각 항목에 끼치는 영향력 정도를 파악하 기 위해 단순회귀분석(Simple Regression Model) 을 실시하였다.

\section{5. 연구모형}

선행연구의 논의를 기반으로 본 연구의 분석모 형을 제시하면 다음과 같다.

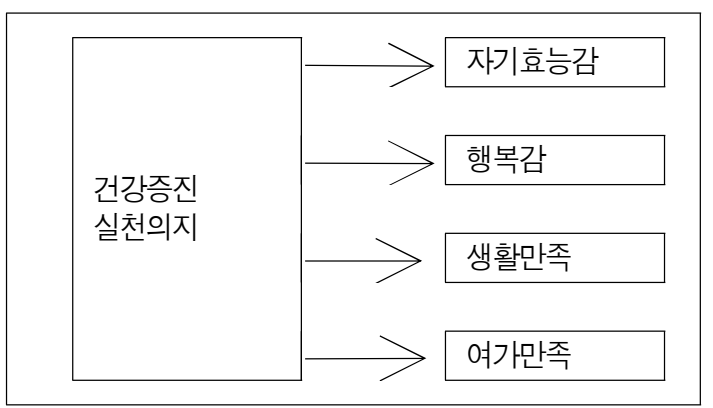

<그림 $1>$ 연구모형
IV. 연구결과

1. 조사대상자의 일반적 특성

조사대상자의 일반적 특성을 정리한 내용은 <표 1>과 같다. 먼저, 성별은 남학생의 비율이 $33.7 \%$, 여학생의 비율이 $66.3 \%$ 로 여학생의 비율이 높았다. 남학생의 경우 군대경험의 유무를 살펴보 면 군대경험이 없는 남학생의 비율이 높았다.

<표 1> 조사대상자의 인구사회학적 특성

\begin{tabular}{|c|c|c|c|}
\hline 항목 & 구분 & 명 & $\%$ \\
\hline \multirow{2}{*}{ 성별 } & 남 & 274 & 33.7 \\
\hline & 여 & 539 & 66.3 \\
\hline \multirow{3}{*}{$\begin{array}{l}\text { 군대 } \\
\text { 경험 }\end{array}$} & 있다 & 188 & 23.2 \\
\hline & 없다 & 619 & 76.3 \\
\hline & 학군단 & 4 & .5 \\
\hline \multirow{4}{*}{ 학년 } & 1학년 & 175 & 21.6 \\
\hline & 2학년 & 295 & 36.3 \\
\hline & 3학년 & 153 & 18.8 \\
\hline & 4학년 & 189 & 23.3 \\
\hline \multirow{2}{*}{$\begin{array}{l}\text { 대학 } \\
\text { 형태 }\end{array}$} & 2년제 & 35 & 4.3 \\
\hline & 4년제 & 779 & 95.7 \\
\hline \multirow{2}{*}{$\begin{array}{l}\text { 학교 } \\
\text { 소재지 }\end{array}$} & 부산 & 609 & 75.1 \\
\hline & 경남 & 202 & 24.9 \\
\hline \multirow{5}{*}{ 종교 } & 기독교 & 245 & 30.3 \\
\hline & 천주교 & 59 & 7.3 \\
\hline & 불교 & 154 & 19.1 \\
\hline & 종교없음 & 345 & 42.7 \\
\hline & 기타 & 5 & 6 \\
\hline \multirow{8}{*}{ 전공 } & 인문계열 & 81 & 10.0 \\
\hline & 사회계열 & 543 & 66.9 \\
\hline & 상과계열 & 37 & 4.6 \\
\hline & 법과계열 & 6 & 0.7 \\
\hline & 자연계열 & 42 & 5.2 \\
\hline & 공학계열 & 42 & 5.2 \\
\hline & 예체능계열 & 46 & 5.7 \\
\hline & 기타 & 15 & 1.8 \\
\hline
\end{tabular}


응답자의 학년비율은 저학년이 $57.9 \%$, 고학년이 $42.1 \%$ 로 저학년이 더 많았고 종교에 있어서는 무 교가 $42.7 \%$, 기독교가 $30.3 \%$, 불교가 $19.1 \%$. 천주 교가 $7.3 \%$ 의 수준 이였다. 전공별로는 사회계열에 $66.9 \%$ 로 가장 많았으며 법과계열이 $0.7 \%$ 로 가장 적었다.

2. 건강증진 실천의지

건강증진 실천의지를 측정하는 문항은 총 11 개 로서 5점 척도로 측정된 각각의 점수를 합한 후 평균하여 건강증진 실천의지의 대표값으로 정의하 였다. 건강증진 실천의지는 <표 2>에서 보는 것과
같이 유효 응답수가 798 개이며, 최소값 1.18 점, 최 대값 5.00점이다. 평균값은 3.56점이며, 표준편차는 0.59 로 나타났다.

<표 2> 조사대상자의 건강증진 실천의지

\begin{tabular}{cccc}
\hline \multirow{2}{*}{ 건강증진 실천의지 } & 명 & 평균 & 표준편차 \\
\cline { 2 - 4 } & 798 & 3.5576 & .59379 \\
\hline
\end{tabular}

건강증진 실천의지 점수 분포를 알아보기 위해 히스토그램을 살펴보면 아래 <그림 2>와 같다.

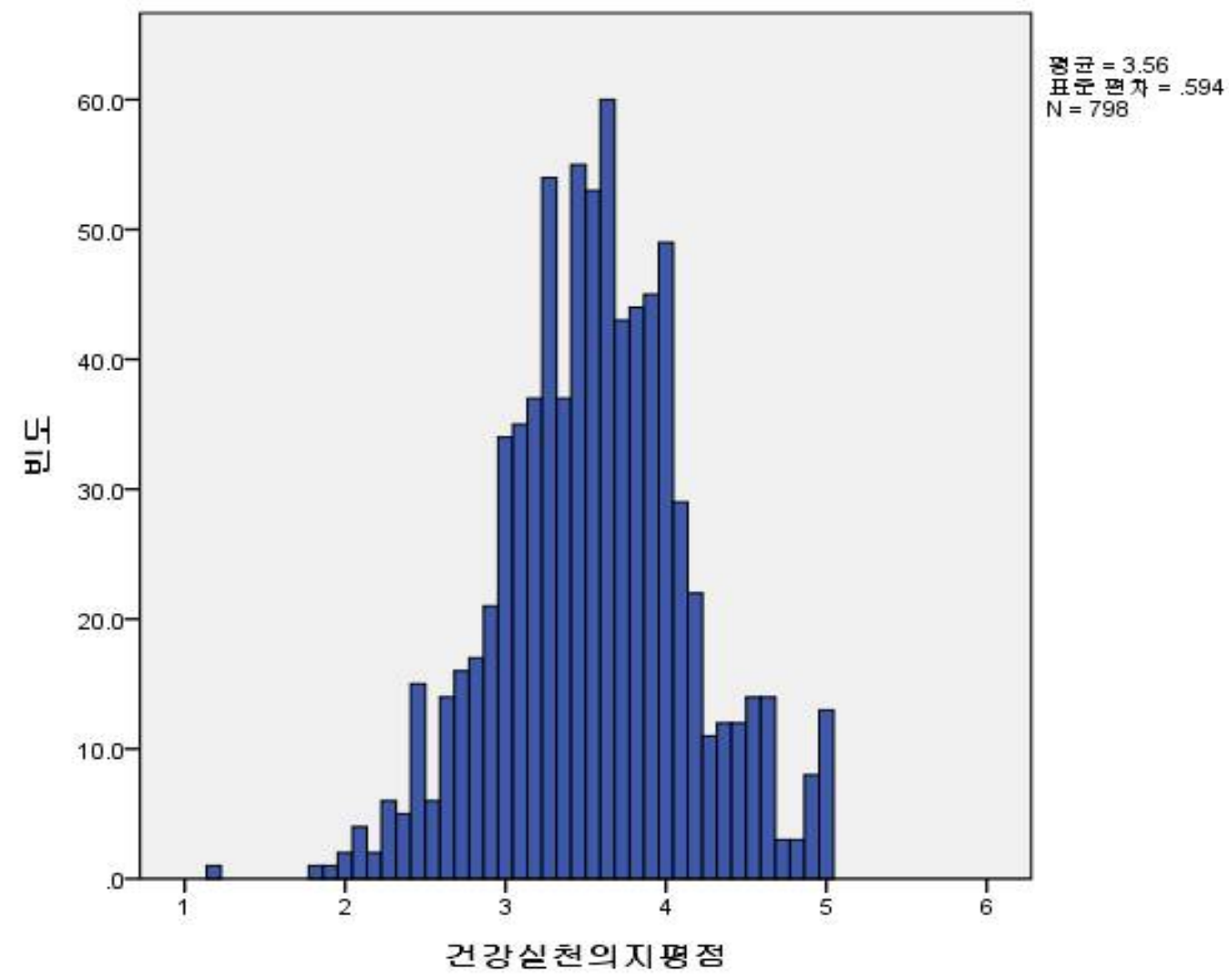

<그림 2> 건강증진 실천의지 점수 분포 히스토그램 
건강증진 실천의지는 대체로 정규분포를 따르고 있으며. 본 연구에서는 건강증진 실천의지의 점수 에 따라 순위변수로 변환하는 과정을 거쳤으며 3 분위로 설정하여 상, 중, 하 3 개 집단으로 나누었 다.

3. 건강증진 실천 의지와 자기효능감, 행복, 생활만족, 여가만족의 관계 분석

1) 건강증진 실천의지와 행복의 관계

먼저, 건강증진 실천의지와 행복 간의 상관관계 를 살펴본 결과, 피어슨 상관계수는 .445이며, $\mathrm{p}$ 값 은 0.01 수준에서 유의하였다. 이는 두 변수 간에 정적인 상관관계가 있음을 나타낸다.

다음으로, 건강증진 실천의지가 상, 중, 하인 3 개의 집단 간에 행복감의 차이가 있는지를 알아보 기 위해 분산분석(ANOVA)를 실시하였다. 분석 결 과는 아래 <표 3>과 같다.

<표 3> 건강실천의지와 행복 분산분석

\begin{tabular}{|c|c|c|c|c|c|c|}
\hline & $\begin{array}{l}\text { 건강증진 } \\
\text { 실천의지 }\end{array}$ & 명 & 평균 & 표준편차 & $F$ & $p$ \\
\hline \multirow{4}{*}{ 행복 } & 상 & 271 & 3.70 & .489 & \multirow{4}{*}{74.392} & \multirow{4}{*}{.000} \\
\hline & 중 & 241 & 3.42 & .415 & & \\
\hline & 하 & 259 & 3.22 & .447 & & \\
\hline & 합계 & 771 & 3.45 & .494 & & \\
\hline
\end{tabular}

분산분석 결과, 건강증진 실천의지가 가장 높은 집단의 행복은 3.70 점이며, 중 수준인 집단은 3.42 , 하 수준인 집단은 3.22 로 건강증진 실천의지가 높 은 집단일수록 행복 또한 높은 것을 알 수 있다. $\mathrm{F}$ 값은 74.392 이며 $\mathrm{p}$ 값은 .000 으로 집단 간 평균차이 는 통계적으로 유의미하게 나타났다.
<표 4> 건강증진 실천의지와 행복의 단순회귀분석

\begin{tabular}{|c|c|c|c|c|}
\hline & \multicolumn{2}{|c|}{ 비표준화 계수 } & \multirow{2}{*}{$\begin{array}{c}\text { 표준화 계수 } \\
\text { 베타 }\end{array}$} & \multirow{2}{*}{$t$} \\
\hline & B & 표준 오차 & & \\
\hline (상수) & 2.128 & .097 & & $21.897 * * *$ \\
\hline $\begin{array}{l}\text { 건강증진 } \\
\text { 실천의지 }\end{array}$ & .372 & .027 & .445 & $13.798 * * *$ \\
\hline R2 & \multicolumn{4}{|c|}{.198} \\
\hline $\mathrm{F}$ & \multicolumn{4}{|c|}{$190.374 * * *$} \\
\hline
\end{tabular}

이어 <표 $4>$ 를 살펴보면, 건강증진 실천의지의 행복에 대한 영향력을 파악하기 위해 단순회귀분 석을 실시한 결과, 건강증진 실천의지 항목의 $\mathrm{B}$ 값 은 0.372, $\mathrm{p}<.001$ 수준에서 유의미하게 나타났다. 따라서 회귀식은 행복 $=2.128+(0.372 \times$ 건강증진 실 천의)이며 이 모델의 설명력은 $19.8 \%$ 이다. $\mathrm{F}$ 값은 190.374로 p<.001 수준에서 통계적으로 유의미하 다.

2) 건강증진 실천의지와 자기효능감과의 관계

첫째, 건강증진 실천의지와 자기효능감 항목 간 의 피어슨 상관계수는 0.396 이며, 유의수준 $1 \%$ 에서 통계적으로 유의미하다. 둘째, 건강증진 실천의지 에 따른 자기효능감의 정도를 비교하기 위해, 분산 분석을 실행한 결과는 아래 <표 5>와 같다.

\begin{tabular}{cccccc} 
<표 5> 건강증진 실천의지와 자기효능감의 분산분석 \\
\hline $\begin{array}{c}\text { 건강증진 } \\
\text { 실천의지 }\end{array}$ & 명 & 평균 & 표준편차 & $F$ & $p$ \\
\hline \hline 상 & 277 & 4.05 & .573 & & \\
자기 중 & 247 & 3.71 & .581 & & \\
효능감하 & 268 & 3.49 & .641 & & .000 \\
$\quad$ 합계 & 792 & 3.76 & .642 & & \\
\hline
\end{tabular}

건강증진 실천의지가 높은 집단은 자기효능감이 4.05 로 높게 나타났으며, 중인 집단은 3.71 , 하인 
집단은 3.49 로 건강증진 실천의지가 높을수록 자기 효능감이 높게 나타난다. 집단 간 분산분석 결과 $\mathrm{F}$ 값은 59.569이며 $\mathrm{p}$ 값은 .000이므로 $\mathrm{p}<.001$ 수준에 서 통계적으로 유의미하게 나타났다.

\begin{tabular}{|c|c|c|c|c|}
\hline & \multicolumn{2}{|c|}{ 비표준화 계수 } & \multirow{2}{*}{$\begin{array}{c}\text { 표준화 계수 } \\
\text { 베타 }\end{array}$} & \multirow{2}{*}{ t } \\
\hline & $\mathrm{B}$ & 표준 오차 & & \\
\hline (상수) & 2.2229 & ".128 & & $\overline{17.457 * \star *}$ \\
\hline $\begin{array}{l}\text { 건강증진 } \\
\text { 실천의지 }\end{array}$ & .429 & .035 & .396 & $12.116 * * *$ \\
\hline R2 & \multicolumn{4}{|c|}{.157} \\
\hline F & \multicolumn{4}{|c|}{$146.799 * * \star$} \\
\hline
\end{tabular}

$* * * p<0.001$

셋째, 자기효능감에 대한 건강증진 실천의지의 영향력을 살펴보기 위해 표6에서 단순회귀분석을 실행한 결과, 건강증진 실천의지 항목의 $\mathrm{B}$ 값은 .429 이며 t값은 12.116 으로 유의확률 $1 \%$ 수준에서 통계적으로 유의미한 것으로 나타났다. 따라서 회 귀식은 자기효능감 $=2.229+(0.429 \times$ 건강실천의지 $)$ 이다. 이 모델의 설명력은 $15.7 \%$ 이며, $\mathrm{F}$ 값은 146.799 로 $\mathrm{p}<0.001$ 이므로 유의미하다.

3) 건강증진 실천의지와 생활만족도의 관계 분석

먼저, 건강증진 실천의지와 생활만족도 간 상관 관계 분석 결과, 피어슨 상관계수는 0.351 이며, $\mathrm{p}$ 값 은 0.01 수준에서 유의하다. 건강증진 실천의지와 생활만족도 간에는 정적인 상관관계가 있음을 알 수 있다.

다음으로, 건강증진 실천의지 정도에 따른 생활 만족 정도를 비교하기 위해 분산분석을 실시한 결 과는 아래 <표 7>과 같다.
<표 7> 건강증진 실천의지와 생활만족도 분산분석

\begin{tabular}{lllllll}
\hline & $\begin{array}{c}\text { 건강증진 } \\
\text { 실천의지 }\end{array}$ & 명 & 평균 & 표준편차 & $F$ & $p$ \\
\hline \hline \multicolumn{1}{c}{ 상 } & 279 & 3.52 & .784 & & \\
생활 & 중 & 248 & 3.13 & .716 & & \\
만족도 하 & 269 & 2.95 & .726 & 42.146 & .000 \\
& 합계 & 796 & 3.20 & .781 & & \\
\hline \multirow{2}{*}{$* * * p<0.001$} & & & & & \\
& & & & &
\end{tabular}

건강증진 실천의지가 상인 집단은 생활만족도가 3.52 로 가장 높게 나타났으며, 중인 집단은 3.13 , 하인 집단은 2.95로 나타났다. 건강실천의지가 높 을수록 생활만족도도 높은 것을 알 수 있다. 분산 분석 결과 $\mathrm{F}$ 값은 42.146 이며 $\mathrm{p}$ 값은 .000으로 유의 확률 $1 \%$ 수준에서 통계적으로 유의미하다. 마지막 으로, 생활만족도에 대한 건강증진 실천의지의 영 향력을 알아보기 위해 단순회귀분석을 실시한 결 과는 <표 8>과 같다.

<표 8> 건강증진 실천의지와 생활만족도 단순회귀분

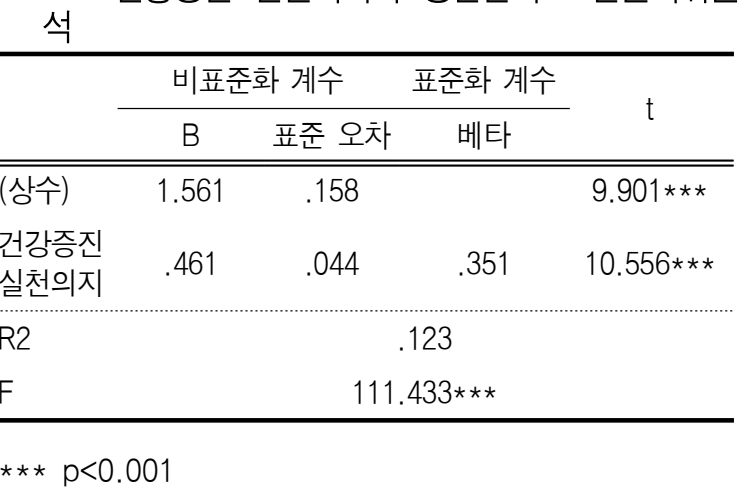

건강증진 실천의지 항목의 $\mathrm{B}$ 값은 .461 이며, $\mathrm{t}$ 값 은 10.556 으로 유의수준 $1 \%$ 범위 내에서 유의미하 다. 따라서 생활만족도에 대한 건강증진 실천의지 의 회귀식은 생활만족도 $=1.561+(0.461 \times$ 건강실천의 지)이다. 즉, 건강증진 실천의지는 생활만족도에 0.461 만큼의 영향력을 가지는 것으로 판단된다. 이 모델의 설명력은 $12.3 \%$ 이며, $\mathrm{F}$ 값은 111.433 으로 $\mathrm{p}<0.001$ 수준에서 유의미하다. 
4) 건강증진 실천의지와 여가만족과의 관계 건강증진 실천의지와 여가만족도 간 상관관계 분석 결과, 피어슨 상관계수는 0.391 이며, $\mathrm{p}$ 값은 유 의수준 $1 \%$ 내에서 유의미하다. 건강증진 실천의지 에 따른 여가만족도의 차이를 살펴보기 위해 건강 증진 실천의지 상, 중, 하 집단별로 평균을 비교한 결과는 아래 <표 9>와 같다.

<표 9> 건강증진 실천의지별 여가만족도 분산분석

\begin{tabular}{cccccc}
\hline $\begin{array}{c}\text { 건강증진 } \\
\text { 실천의지 }\end{array}$ & 명 & 평균 & 표준편차 & $F$ & $\mathrm{p}$ \\
\hline \hline 상 & 274 & 3.71 & .666 & & \\
여가 중 & 245 & 3.39 & .542 & & \\
만족도 하 & 266 & 3.14 & .658 & 5.713 & .000 \\
합계 & 785 & 3.42 & .669 & & \\
\hline \multirow{2}{*}{ *** $\mathrm{p}<0.001$} & & & & & \\
\end{tabular}

건강증진 실천의지가 상 집단의 여가만족도는 평균 3.71로 나타났으며, 중 집단은 3.39 , 하 집단 은 3.14로 나타났다. 건강증진 실천의지가 높을수 록 여가 만족도도 높은 것으로 설명할 수 있다. 집 단 간 차이를 알아보기 위한 분산분석 결과 $\mathrm{F}$ 값은 $55.713, \mathrm{p}$ 값은 0.000 으로 유의수준 $1 \%$ 수준에서 건 강증진 실천의지 수준에 따른 집단별 평균 차이는 통계적으로 유의미하다고 할 수 있다.

<표 10> 건강증진 실천의지와 여가만족의 단순회귀분석

\begin{tabular}{|c|c|c|c|c|}
\hline & \multicolumn{2}{|c|}{ 비표준화 계수 } & \multirow{2}{*}{$\begin{array}{c}\text { 표준화 계수 } \\
\text { 베타 }\end{array}$} & \multirow{2}{*}{ t } \\
\hline & B & 표준 오차 & & \\
\hline (상수) & 1.851 & .134 & & $13.839 * * *$ \\
\hline $\begin{array}{l}\text { 건강증진 } \\
\text { 실천의지 }\end{array}$ & .440 & .037 & 391 & $11.871 *$ \\
\hline R2 & \multicolumn{4}{|c|}{.153} \\
\hline $\mathrm{F}$ & \multicolumn{4}{|c|}{$140.919 * *$} \\
\hline
\end{tabular}

$p<0.001, * * p<0.01$

<표 10>에서 살펴보면 여가만족에 대한 건강증
진 실천의지의 영향력을 평가하기 위해 단순회귀 분석을 실행한 결과, 건강증진 실천의지 변수의 B 값은 .440, t값은 11.871 로 유의확률 $1 \%$ 수준에서 통계적으로 유의미한 것으로 나타났다. 회귀식은 여가만족 $=1.851+(0.440 \times$ 건강증진 실천의지 $)$ 이며 이 모델의 설명력은 $15.3 \%$ 이다. F값은 140.919 로 유의 수준 $1 \%$ 에서 통계적으로 유의미하다.

\section{IV. 결론 및 제언}

본 연구에서는 대학생들 건강증진실천의지가 자 기효능감, 행복, 생활만족, 여가만족에 어떠한 영향 을 미치는지 분석하고자 하였다. 이를 위해 건강증 진실천의지 정도를 상·중·하로 그룹으로 나누어 살 펴보았으며, 그 결과를 요약하면 다음과 같다.

첫째, 건강증진 실천의지와 자기효능감과의 관 계는 정적상관관계가 있음으로 나타났으며, 건강증 진 실천의지가 높을수록 자기효능감이 높게 나타 났다. 자기효능감에 대한 건강증진 실천의지의 영 향력을 살펴보기 위해 단순회귀분석을 실행한 결 과, 통계적으로 유의미하게 나타났으며, 이 모델의 설명력은 $15.7 \%$ 이다.

둘째, 건강증진 실천의지와 행복의 관계는 정적 상관관계가 있음으로 나타났으며, 건강증진 실천의 지가 높은 집단일수록 행복수준이 높은 것으로 나 타났다. 건강증진 실천의지의 행복에 대한 영향력 을 파악하기 위해 단순회귀분석을 실시한 결과, 통 계적으로 유의미하게 나타났으며, 이 모델의 설명 력은 $19.8 \%$ 이다.

셋째, 건강증진 실천의지와 생활만족도의 관계 는 정적 상관관계가 있으며, 건강실천의지가 높을 수록 생활만족도가 높게 나타났다. 생활만족도에 대한 건강증진 실천의지의 영향력을 알아보기 위 해 단순회귀분석을 실시한 결과 통계적으로 유의 미하여, 이 모델의 설명력은 $12.3 \%$ 이이다. 
넷째, 건강증진 실천의지와 여가만족과의 관계 는 정적 상관관계가 있으며, 건강증진 실천의지가 높을수록 여가 만족도도 높게 나타났다. 여가만족 에 대한 건강증진 실천의지의 영향력을 평가하기 위해 단순회귀분석을 실행한 결과, 통계적으로 유 의미한 것으로 나타났으며, 이 모델의 설명력은 $15.3 \%$ 이다.

이상과 같이 건강증진 실천의지를 상·중·하 세 그룹으로 나누어 자기효능감, 행복, 생활만족, 여가 만족과의 관계에서 건강증진 실천의지가 높을수록 모두 긍정적인 영향을 미친다는 것을 확인하였다. 건강은 대학생의 생활영역에서 중요한 자신에 대 한 효능감, 전반적인 행복감, 생활만족 뿐 아니라 여가만족에 있어서도 긍정적인 영향을 미칠 수 있 는 중요한 요인임을 다시 확인할 수 있었다. 대학 생은 신체적, 정신적 발달단계에 놓여있는 초기성 인으로 점차적으로 자신의 건강에 대하여 책임감 을 가지게 되지만, 잘못된 습관과 행동 때문에 건 강을 해치기 쉽다[13]. 또한 성인중기 및 후기에 비해 상대적으로 건강습관이 확고히 형성되지 않 아 건강행위의 수정가능성이 크고, 이 시기에 정착 된 건강습관은 성인중기 및 후기의 건강행위의 기 반이며, 미래의 부모로서 건강에 대한 태도, 실천 은 자녀의 건강실천에 중요한 영향을 미친다[14]. 대학생 시기에는 삶의 본질과 이유, 미래에 대하여 진지하게 사유하고, 삶에 대한 가치창조와 인성적 자질, 사회적 관계 능력 등을 배양하는 것이 중요 하다. 인간과 자신에 대한 이해를 위한 교육과 경 험으로 대학생들은 심리, 사회, 정신적 건강뿐 아 니라 졸업 후 취업의 장에서 보다 폭넓은 전문가 적 소양을 갖출 기본을 마련하는 시기이기 때문이 다. 그러므로 생애 가장 소중한 시기를 보내고 있 는 그들이 과연 행복에는 건강이라는 중요한 기본 적인 요인이 있음을 간과해서는 안 된다. 건강증진 에 대한 인식을 통해 스스로 실천할 수 있도록 하 는 것은 남은 인생을 건강하게 살아갈 수 있게 하
는 기본임을 강조하고자 한다.

본 연구를 진행하면서 연구의 한계점 및 후속연 구에 대한 제언을 다음과 같이 하고자 한다. 첫째, 연구의 결과를 논의하면서 변인들의 관계를 살펴 보기도 하였지만, 차후, 대학생들의 생활에 있어 가장 중요한 요인들을 추가적으로 포함하여 구조 방정식 분석 등을 통한 좀 더 세부적인 인과관계 를 검증해 볼 필요가 있다.

둘째, 본 연구는 부산·경남의 4 년제 대학생을 대상으로 하여 수도권과 비수도권의 진로 관련 요 인의 비교는 가능하지 않은 한계가 있다. 비수도권 학생의 경우 수도권보다 학업의 환경이나 문화적 인 차이 등의 지역적인 특색 고려가 되지 않은 점 이 있을 것이다.

셋째, 대학생들의 건강증진실천의지에서 머무르 지 않고 건강증진 실천 프로그램을 교양수업이나 동아리 활동 등을 통해 스스로의 건강증진 뿐 아 니라 대학생들의 역량으로 지역사회에 건강증진 실천을 위한 봉사 등으로 건강한 지역사회 확산의 역할을 할 수 있으리라 기대된다. 따라서 대학 내 의 정규 교양수업, 동아리, 지역사회 연계한 프로 그램의 활성화 등이 필요하다.

넷째, 본 연구에서는 건강실천의지가 각 변수에 관한 영향력만을 분석하였지만, 추후 연구에서는 쌍방향으로 자기효능감이 건강실천의지에 영향을 미치는지 여부에 관한 것도 살펴보면 더욱더 의미 있는 자료로 활용되리라 생각된다.

위에서 제시한 제한점들이 있음에도 불구하고 본 연구에서 보고자 하였던 것은 건강에 대한 실 천의지가 대학생의 중요한 변수에 어떠한 영향을 미치는가를 보고자 하였다. 즉, 건강은 아무리 강 조해도 지나치지 않다. 건강할 때는 그 소중함을 잊고 산다고 하지만, 가장 건강하고 체력적으로 왕 성하고 건강한 대학생 시기에 자신의 건강을 위해 노력하는 것은 자신을 사랑하고 가치 있게 인식하 며, 행복과 생활의 만족, 나아가 여가만족까지 긍 
정적으로 영향을 미친다는 것을 실증적으로 확인 하였다. 본 연구의 저자들은 행복에 관하여 오랜 시간 동안 가지고 왔던 관심에서 대학생의 건강증 진실천의지와 관련하여 연구결과를 살펴보았다. 추 후 연구대상을 확대하고 영향요인을 다르게 하여 더 심층적인 연구를 할 수 있는 탐색적 차원에서 의 하나의 초석을 마련하였다고 생각한다.

\section{참고문헌}

1. Betz, N. E., \& Hackett. G(2006), Career self-efficacy: Back to the future. Journal of Career Assessment, Vol.14(2) 3-11.

2. 박장근, 이순환, 이용호, 임란희(2008), 한국과 미 국 대학생들의 개인별 특성에 따른 여가태도 차 이. 한국사회체육학회지, Vol.32(1);1333-1342.

3. Cottrell,C.,Neuberg,S.L.,\& Li,N.P.(2007), What do people desire in others? asociofunctional perspective on the importance of different valued characteristics, Journal of Personality and Social Psychology, Vol.92(1);208-231.

4. 김태운(2002), 여가활동 참여 대학생의 라이프스타 일과 건강증진 행위 및 대학 조직만족도 간의 인 과모형 연구, 한국체육학회지, Vol.41(3);125-137.

5. 김애경(1995), 건강행위에 대한 한국청년의 주관성 연구, 대한간호, Vol.34(1);50-54.

6. World Health Organization (2006), School health and youth health promotion, website: http://www.who.int/school_youth_health/en/.

7. 김남순, 송현종(2004), 한국여성의 만성질환현황과 정책과제, 보건복지포럼, Vol.93;39-46.

8. 한국여성개발원(2006), 여성통계자료: 건강, web site: http://www.kwdi.re.kr.

9. 김주현, 김성재, 박연환(2001), 여대생의 건강증진 행위에 영향을 미치는 요인.

성인간호학회지, Vol.13(3), 431-440.
10. 황흥구(2008), 대학생들의 건강증진행위에 영향을 미치는 요인, 대구대학교 박사학위논문.

11. 류은정, 권영미, 이건세(2001), 대학생의 사회심리 적 건강과 건강증진 생활양식 이행, 보건교육건강 증진학회지, Vol.18(1);49-60.

12. 남희은(2005), 저소득층 노인의 여가교육 프로그 램 효과성 연구, 이화여자대학교 일반대학원 석사 학위논문, pp. 17-49

13. Regina(2005), L. T. Lee, \& Alice, J. T Yuen Loke., Health promoting behaviors and psychosocial well-being of university students in Hong-Kong, Public Health Nurs, Vol.22(3); 209-220.

14.Yarcheski A., Mahon NE.(1989), A causal model of positive health practices; The relationship between approach and replication, Nursing Research, Vol.38(2);88-93.

접수일자 2012년 2월 20일

심사일자 2012년 2월 22일

게재확정일자 2012년 2월 27일 